\title{
24-hour Fire Produced Effect on Reinforced Recycled Aggregates Concrete Beams
}

\author{
Abdul Hafeez Buller \\ Department of Civil Engineering, Quaid-e-Awam \\ University of Engineering, Science \& Technology, \\ Nawabshah, Pakistan \\ ah.buller@quest.edu.pk
}

Bashir Ahmed Memon

Department of Civil Engineering, Quaid-e-Awam University of Engineering, Science \& Technology, Nawabshah, Pakistan

bashir_m@hotmail.com

\author{
Mahboob Oad \\ Department of Civil Engineering, Quaid-e-Awam \\ University of Engineering, Science \& Technology, \\ Nawabshah, Pakistan \\ engrmahbooboad04@gmail.com \\ Samiullah Sohu \\ Department of Civil Engineering, Quaid-e-Awam \\ University of Engineering Science \& Technology, \\ Campus Larkana, Pakistan \\ sohoosamiullah@gmail.com
}

\begin{abstract}
In this article, the effect of prolonged fire (24-hour duration) on reinforced concrete beams made with recycled aggregates from demolished concrete was experimentally investigated. Demolished concrete was used recycled coarse aggregates in equal proportion with natural coarse aggregates. Normal and rich mix concrete with water-cement ratio equal to 0.54 were used. As a control specimen, beams with all-natural aggregates were also cast to compare with the results of the proposed beams. All beams were cured for 28 days and exposed to fire at $1000^{\circ} \mathrm{C}$ in an oven for 24 hours. After the elapse of this fire period, the beams were allowed to air cool, followed by testing till failure in a universal load testing machine. Comparison of the test results shows that rich mix concrete beams more reduction in flexural strength, more increase in maximum load carrying capacity and deflection than normal mix beams. The maximum reduction in flexural strength was $32.41 \%$ for beams cast with 50\% RCA and rich mix. Although the fire duration used in this study is rare, yet the outcome provides guidelines for taking proper decisions for retrofitting/strengthening of the fire affected structure before putting it back in service.
\end{abstract}

Keywords-green concrete; fire effect; flexural behavior; demolished waste; recyclable aggregates

\section{INTRODUCTION}

Green concrete, particularly the concrete produced by using demolished concrete as aggregates has a wide acceptance among researchers and the construction industry, because it is environment friendly, reduces environmental hazards, reduces waste management issues by its on-site consummation in new concrete, and it is less costly. However, its properties and behavior to various effects should be well understood to develop good confidence level on the material, which in turn will lead to assurance of strength and durability during the service life of the structure. Fire is among several hazards, natural or accidental, which a structure may meet. Fire not only affects the appearance by damaging the cladding but due to thermal stresses and high temperature, affects strength. Fire would affect the green concrete made with demolished concrete as aggregates. Green concrete on the other hand is a relatively new material, thus its behavior should be studied particularly at elevated temperatures for longer duration to set the guidelines for industry and researchers.

Several researchers are actively engaged in evaluating the properties and behavior of green concrete made with demolishing waste [1-3]. Author in [1] reviewed the recent developments regarding the use of demolishing waste in new concrete with respect to challenges, recycling and behavior of green concrete. Authors in [2] reviewed the properties, strength parameters and property numerical equations of green concrete evaluated by several researchers among the available state-ofthe-art on the subject. Authors in [3] also reviewed the state-ofthe-art, particularly with regard to the waste generated due to heavy floods in BH Serbia. Based on the available research about the material, they concluded that waste can be used to produce conventional and even high-quality concrete subjected to the properties of aggregates from waste. Compressive strength of concrete with demolished concrete as coarse aggregates in different dosages has been studied in [4]. From the experimental results, the authors found that $50 \%$ replacement of natural aggregates is the optimum dosage. With this replacement the reduction in strength is minimum. The flexural behavior of reinforced recycled aggregate concrete beams was studied with the use of normal and rich mixes in [5] and [6] respectively. Based on the laboratory findings, the authors observed that the flexural behavior of green concrete beams is in good agreement with the conventional concrete beams. Also, they observed that the deflection in the proposed beams remained within the allowable limits of approximate deflection given by ACI-318.

Towards the evaluation of effect of fire on green concrete, several attempts have been made using different temperatures and fire durations. Green concrete cubes made with demolished 
concrete as coarse aggregates have been used in [7] to check the effect of $1000^{\circ} \mathrm{C}$ for $6 \mathrm{~h}$. The authors used different dosages of recyclable aggregates. The compressive strength test results of these fire exposed cubes revealed that with $50 \%$ replacement the reduction in compressive strength is minimum. The compressive strength of recycled concrete exposed to $500^{\circ} \mathrm{C}$ temperature for $1 \mathrm{~h}$ has been investigated in [8]. However, the authors used $75 \%$ replacement of natural coarse aggregates and compared the results with conventional concrete made with different water-cement ratios. Based on the test results by ultrasonic and resonance frequency test, the authors observed that the proposed concrete at the above mentioned temperature and duration performs well in comparison with the conventional concrete of low water-cement ratio. The compressive strength of concrete cubes made with $0 \%$ to $100 \%$ (with increment of $25 \%$ ) recycled aggregates and heated in electronic oven at $50^{\circ} \mathrm{C}, 100^{\circ} \mathrm{C}, 200^{\circ} \mathrm{C}, 300^{\circ} \mathrm{C}$, and $400^{\circ} \mathrm{C}$ for $8 \mathrm{~h}$ has also been studied in [11]. The tests' results showed $38 \%$ average reduction in strength for all replacements when heated up to $200^{\circ} \mathrm{C}$ and $45 \%$ residual strength when heated from $300^{\circ} \mathrm{C}$ to $400^{\circ} \mathrm{C}$. In a similar study, but with different natural aggregate replacement percentages from $0 \%$ to $50 \%$ [15], specimens were heated from $200^{\circ} \mathrm{C}$ to $800^{\circ} \mathrm{C}$. From the test results, the authors concluded that the performance of the recycled aggregate concrete was comparable with the one of conventional concrete. Author in [9] used 50\% and $100 \%$ replacement of natural coarse aggregates with recyclable aggregates to produce green concrete. The specimens were heated to $600^{\circ} \mathrm{C}$ and $800^{\circ} \mathrm{C}$. After heating, the specimens were checked for strength and modulus of elasticity. The authors observed $10 \%$ increase in compressive strength of green concrete with $50 \% \mathrm{RCA}$ and $50 \%$ reduction to $100 \%$ replacement of natural coarse aggregates. However, they reported no influence of elevated temperature and natural coarse aggregates replacement percentage on the elastic modulus. The authors further reported a strong correlation between the elastic modulus and the square root of compressive strength. Authors in [10][10] checked the mechanical properties of 204 concrete cylinders made with recycled concrete aggregates, river gravel and limestone aggregates. The authors used different dosages of the aggregates and heated the cylinders at $20^{\circ} \mathrm{C}, 250^{\circ} \mathrm{C}, 500^{\circ} \mathrm{C}$ and $750^{\circ} \mathrm{C}$. From the test results of compressive and tensile strength, elastic modulus, damage and cracking, they found the proposed concrete to have good performance. Also, they argued that even at the temperature of $750^{\circ} \mathrm{C}$, the proposed concrete did not exhibit any disintegration of the ingredients. In addition to the above, the behavior of fiber reinforced recycled aggregate concrete [12] and geopolymer coated aggregate concrete [13] have been studied. A constitutive theory for recycled aggregate concrete subject to elevated temperatures has been presented in [14]. It may be noted, that a good number of research findings has been published about the properties of recycled aggregate concrete, yet little work is available regarding the effect of high temperatures on recycled aggregate concrete, particularly the effect of longer fire duration $(24 \mathrm{~h})$. This motivated the work presented in this study. It combines the use of recyclable aggregates from demolished concrete and the effect of a $24 \mathrm{~h}$ fire on reinforced concrete beams. It is anticipated that the outcome of the work will set suitable guidelines for the researchers in understanding the behavior of recycled concrete exposed to longer fire durations.

\section{MATERIALS AND TESTING}

For recycled aggregates, old demolished concrete of an about 50-year old school building was obtained in the shape of large blocks. The large pieces were manually reduced to size approximately equal to $20 \mathrm{~mm}$. To ensure well graded aggregates in concrete mix, gradation of both recycled and natural aggregates was done in accordance to ASTM standards. The obtained results are shown in Tables I (recycled aggregates) and II (natural aggregates). Both sets are plotted in Figure 1. Additionally, abrasion test on both types of aggregates was also performed as per the procedure given by ASTM C131-89. The Los Angeles abrasion value for natural aggregates was recorded equal to $18.3 \%$ and $26.7 \%$ for recycled aggregates. The recycled aggregates exhibited $8.4 \%$ more abrasion than natural aggregates. This is mainly due to the old mortar attached with the recycled aggregates. Attempt has been made to separate the mortar powder and pieces, then the abrasion of recycled aggregates was recorded $5.7 \%$ more than the one of natural aggregates. The dosage of recycled aggregates used was $50 \%$. The selection of this dosage is based on the conclusions of [4].

TABLE I. GRADATION OF RECACLED COARSE AGGRAGATES

\begin{tabular}{|c|c|c|c|c|c|}
\hline \multirow{2}{*}{$\#$} & \multirow{2}{*}{$\begin{array}{c}\text { Sieve } \\
(\mathbf{m m})\end{array}$} & \multirow{2}{*}{$\begin{array}{c}\text { Weight } \\
\text { retained (g) }\end{array}$} & \multicolumn{3}{|c|}{ Cumulative } \\
\cline { 4 - 6 } & & Wt. Ret. (g) & Retained (\%) & Passing (\%) \\
\hline 1 & 31.5 & 0.00 & 0.00 & 0.00 & 100.00 \\
\hline 2 & 25 & 95.00 & 95.00 & 4.48 & 95.52 \\
\hline 3 & 19 & 978.00 & 1073.00 & 50.61 & 49.39 \\
\hline 4 & 12.5 & 742.00 & 1815.00 & 85.61 & 14.39 \\
\hline 5 & 9.5 & 262.00 & 2077.00 & 97.97 & 2.03 \\
\hline 6 & 4.75 & 31.00 & 2108.00 & 99.43 & 0.57 \\
\hline 7 & 2.36 & 7.00 & 2115.00 & 99.76 & 0.24 \\
\hline 8 & Pan & 5.00 & 2120.00 & 100.00 & 0.00 \\
\hline
\end{tabular}

TABLE II. GRADATION OF NATURAL COARSE AGGREGATES

\begin{tabular}{|c|c|c|c|c|c|}
\hline & \multirow{2}{*}{$\begin{array}{c}\text { Sieve } \\
\text { (mm) }\end{array}$} & \multirow{2}{*}{$\begin{array}{c}\text { Weight } \\
\text { retained (g) }\end{array}$} & \multicolumn{3}{|c|}{ Cumulative } \\
\cline { 4 - 6 } & & Wt. Ret. (g) & Retained (\%) & Passing (\%) \\
\hline 1 & 31.50 & 0.00 & 0.00 & 0.00 & 100.00 \\
\hline 2 & 25.00 & 55.00 & 55.00 & 2.49 & 97.51 \\
\hline 3 & 19.00 & 945.00 & 1000.00 & 45.25 & 54.75 \\
\hline 4 & 12.50 & 680.00 & 1680.00 & 76.02 & 23.98 \\
\hline 5 & 9.50 & 487.00 & 2167.00 & 98.05 & 1.95 \\
\hline 6 & 4.75 & 37.00 & 2204.00 & 99.73 & 0.27 \\
\hline 7 & 2.36 & 0.00 & 2204.00 & 99.73 & 0.27 \\
\hline 8 & Pan & 6.00 & 2210.00 & 100.00 & 0.00 \\
\hline
\end{tabular}

To reinforce the beams, $4 \# 4$ steel bars were used with two bars in tension and compression zones. To ensure the shear capacity of the beams, \#3 ties at $150 \mathrm{~mm}$ center-to-center were used throughout the length of the beam (Figure 2). The size of all beams was kept the same. A total of 24 beams were cast for the purpose. The details of the beams with respect to curing age, concrete mix and dosage of recycled aggregates are given in Table III. After casting the reinforced concrete beams in standard fashion and water curing for 28 days, all the beams were exposed to fire for $24 \mathrm{~h}$ in an oven made for the purpose. The source of fire was wood and it took almost $1.5 \mathrm{~h}$ to reach $1000^{\circ} \mathrm{C}$, and then the temperature was maintained. During the 
process of heating the temperature was regularly monitored using a digital thermometer (Figure 3). After the elapse of $24 \mathrm{~h}$ the source of fire was cutoff and the beams were left in the oven for a day to avoid sudden attack of atmospheric moisture. Then, the beams were tested until failure under central point load (Figure 4) as per the recommendations of ASTM C293 [17].

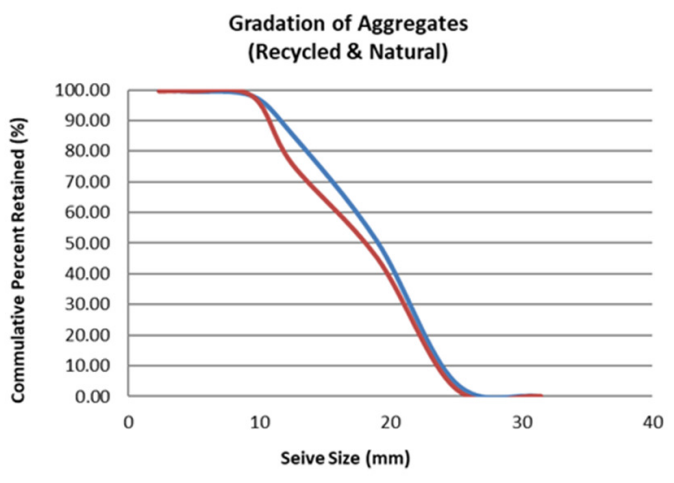

- Recycled Aggregates - Natural Aggregates

Fig. 1. Gradation of RA and NA

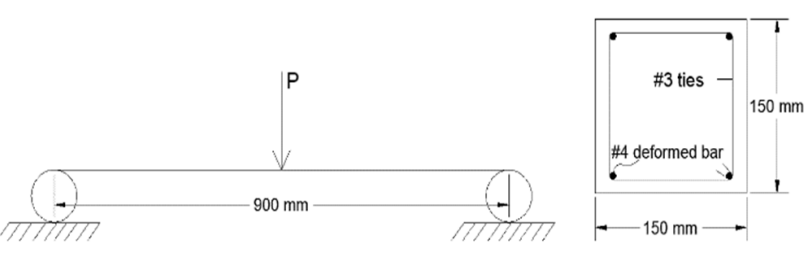

Fig. 2. Model dimensions

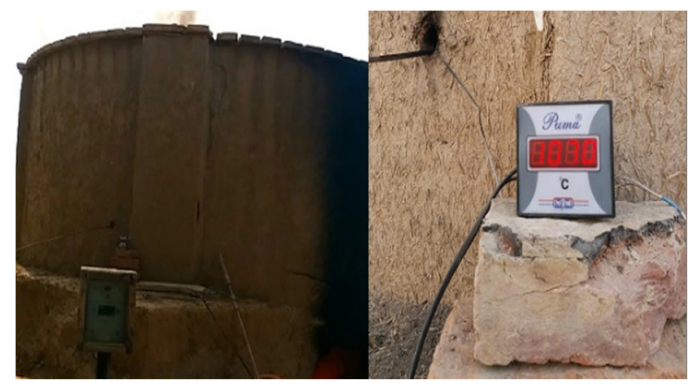

Fig. 3. Temperature monitoring

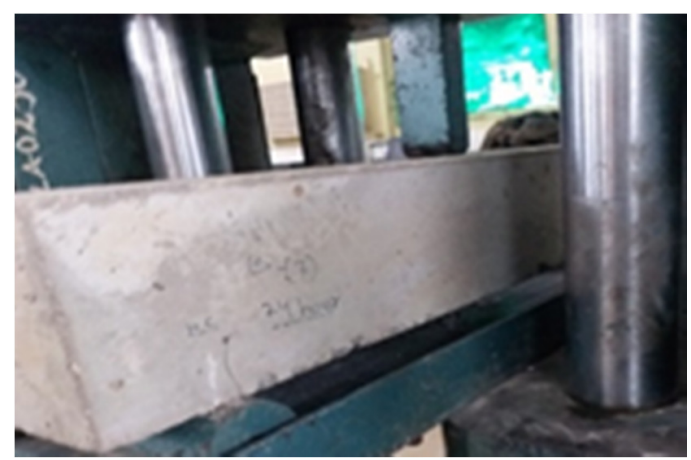

Fig. 4. Beam mounted on the UTM
TABLE III. SPECIMEN DETAILS

\begin{tabular}{|c|c|c|c|c|}
\hline Mix & RCA \% & No of Beams & w/c ratio & Curing (days) \\
\hline \multirow{2}{*}{$1: 2: 4$} & 50 & 6 & 0.54 & 28 \\
\cline { 2 - 5 } & 0 & 6 & 0.54 & 28 \\
\hline \multirow{2}{*}{$1: 1.5: 3$} & 50 & 6 & 0.54 & 28 \\
\cline { 2 - 5 } & 0 & 6 & 0.54 & 28 \\
\hline
\end{tabular}

During the load testing, deflection and cracking were monitored. At failure crack, the pattern was recorded and the flexural strength of the beams was computed using a numerical formula given by the above mentioned ASTM standard.

\section{RESULTS AND DISCUSSION}

The maximum load attained by the reinforced concrete beams is plotted in Figure 5. Average peak load, average deflection, and average flexural strength exhibited by the six beams of the group are given in Table IV. From this Table it may be observed that reinforced concrete beams cast with allnatural aggregates and normal mix showed less maximum load than the beams of the other groups. Considering the maximum load of these beams as control value, the RC beams cast with normal mix and $50 \%$ RCA exhibited $23.57 \%$ reduction. In contrast to normal mix, rich mix beams cast with all-natural aggregates showed $5.67 \%$ reduction in average peak load, while $32.41 \%$ reduction in average peak load was recorded for the beams cast with rich mix and 50\% recycled aggregates. After fire exposure for $24 \mathrm{~h}$, beams showed reduced maximum load. The rich mix beams of both natural and recycled aggregates exhibited reduction in load in comparison to normal mix beams. Even the rich mix concrete beams cast with recycled aggregates showed 3.34KN less maximum load when compared to normal mix beams with the same percentage of recycled aggregates. Therefore, more attention should be given to fire exposed (particularly prolonged fire) structural members cast in rich mix.

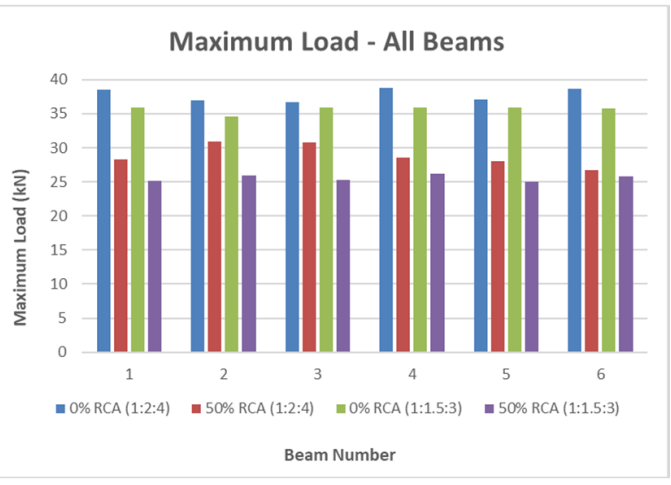

Fig. 5. Maximum load

Figure 6 shows the graphical comparison of the maximum deflection observed by all beams in each group. In this Figure, the increasing trend of deflection may be observed. The maximum deflection is observed in beams cast with 50\% RCA and rich mix and is equal to $12.2 \mathrm{~mm}$. The value in comparison to ACI-318 maximum allowable deflection is about 2.5 times larger. Observation of average values of the deflection shows that normal mix RC beams cast with all-natural aggregates due to exposure to fire showed $9.66 \mathrm{~mm}$ deflection. This is double 
than the ACI-318 allowable values. Considering it as base value, RC beams cast with 50\% RCA and normal mix exhibited $9.92 \%$ more deflection. $8.02 \%$ and $20.10 \%$ increase in deflection was also recorded for rich mix beams cast with $0 \%$ and $50 \%$ RCA. The load-deflection pattern for normal and rich mix beams are shown in Figures 7 and 8 respectively. It may be observed that the trend of load-deflection is the same for all beams except the peak values of the parameters.

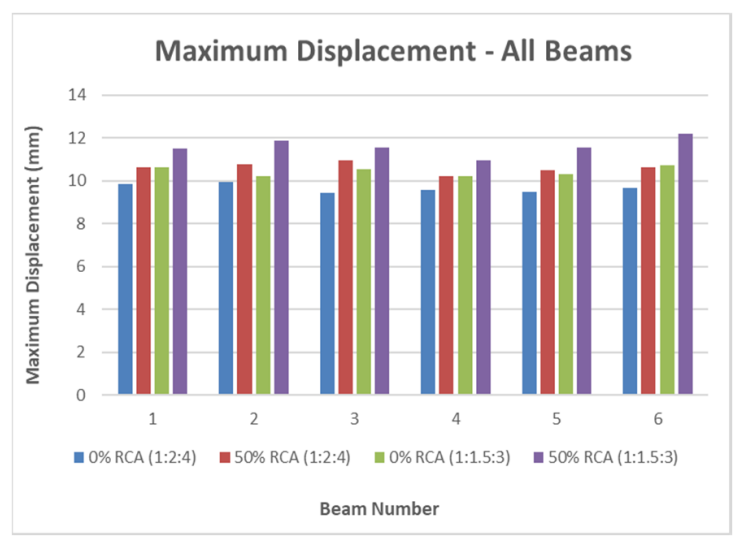

Fig. 6. Maximum deflection

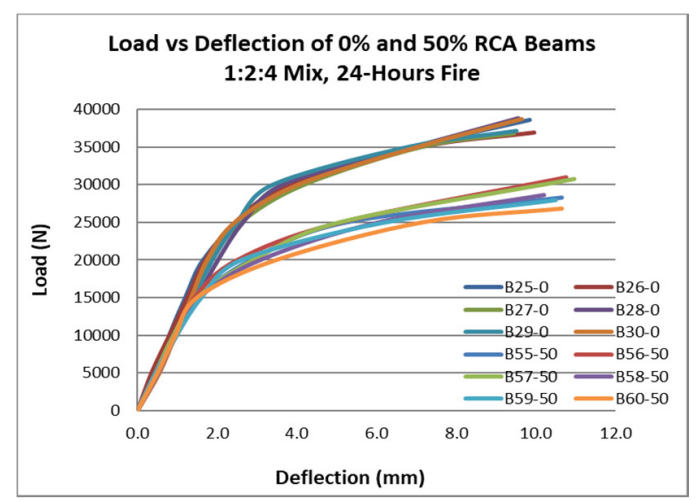

Fig. 7. Load vs deflection of normal mix beams



Fig. 8. Load vs deflection of rich mix beams
TABLE IV. PARAMETER AVARAGE VALUES

\begin{tabular}{|c|c|c|c|c|}
\hline Mix & RCA (\%) & Load & Def & FS \\
\hline $1: 2: 4$ & 0 & 37.80 & 9.66 & 15.12 \\
\hline $1: 2: 4$ & 50 & 28.89 & 10.62 & 11.56 \\
\hline $1: 1.5: 3$ & 0 & 35.66 & 10.43 & 12.89 \\
\hline $1: 1.5: 3$ & 50 & 25.55 & 11.60 & 10.22 \\
\hline
\end{tabular}

The average values of the computed flexural strength are given in Table IV. Considering 0\% RCA, normal mix reinforced concrete beams as control specimen, the average flexural strength attained by rich mix concrete beams of $0 \%$ and $50 \%$ dosage of RCA is shown in Figure 9. Like the reduction in peak load, the reduction in flexural strength is recorded with maximum reduction equal to $32.41 \%$ in rich mix beams with $50 \%$ dosage. It is $20.73 \%$ smaller than its counterpart with all-natural aggregates.

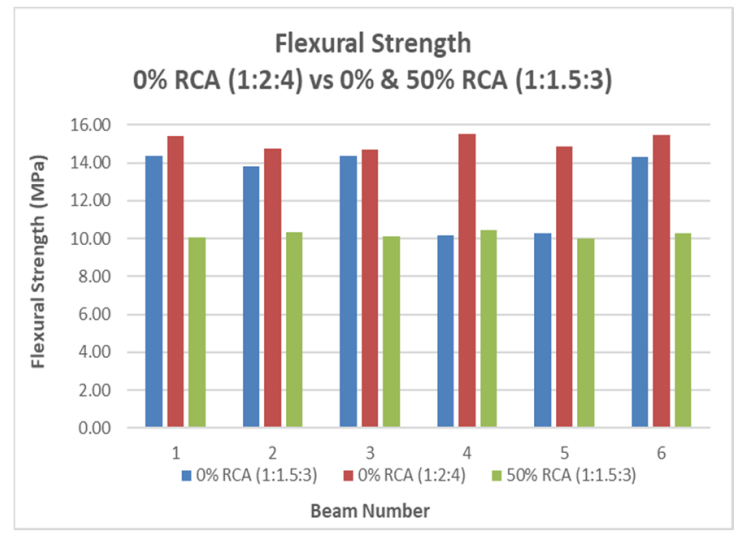

Fig. 9. Average flexural strength (rich mix vs normal mix)

Due to the long fire exposure and cooling process, several hair line cracks appeared on the surface of the beams which made difficult the monitoring of the first crack during testing. Therefore, the crack pattern after failure was recorded. The observations show shear cracks in most of the specimens with few beams showing both flexural and shears cracks. Shear cracks were dominant in all beams. Therefore, the failure mode of the beams is considered as shear failure.

\section{CONCLUSION}

Based on the experimental observations of the reinforced concrete beams exposed to 24-hour fire at $1000^{\circ} \mathrm{C}$, the following observations are made.

- Normal mix reinforced concrete beams exhibited more residual strength than rich mix reinforced concrete beams.

- Due to fire exposure, beams exhibited reduction in maximum load carrying capacity.

- Addition of recycled aggregates added more reduction of maximum load carrying capacity.

- Increasing trend of deflection is recorded in all beams.

- Load-deflection behavior of all beams is similar, except peak values. 
- Maximum of $32.41 \%$ reduction in flexural strength of rich mix reinforced concrete beams cast with $50 \%$ dosage of recyclable aggregates is recorded in comparison to beams cast will all-natural aggregates and normal mix.

- Shear failure in all beams was observed.

Although 24-hour fire is a rare occasion, yet the proposed beams showed minimum of about $68 \%$ residual strength. Therefore, the performance of the beams is comparable with conventional concrete's. Hence, the outcome of this research provides experimental information and sets guidelines regarding the effect of prolonged fire on green concrete made with demolished concrete as coarse aggregates.

\section{REFERENCES}

[1] B. A. Memon, "Recent development on use of demolished concrete as coarse aggregates", International Journal of Emerging Technology and Innovative Engineering, Vol. 2, No. 1, pp. 1-11, 2016

[2] B. G. Fonteboa, S. Seara-Paz, J. D. Brito, I. G. Taboada, F. M. Abella, R. V. Silva, "Recycled concrete with coarse recycled aggregates. An overview and analysis", Materiales de Construccion, Vol. 68, No. 330, 2018

[3] M. Malesev, V. Radonjanin, G. Broceta, "Properties of recycled aggregate concrete", Contemporary Materials, Vol. 2, pp. 239-249, 2014

[4] M. Oad, B. A. Memon, "Compressive Strength of Concrete Cylinders Using Coarse Aggregates from Old Concrete", 1st National Conference on Civil Engineering, Modern Trends and Advancements, Pakistan, April 28-29, 2014

[5] M. Oad, A. H. Buller, B. A. Memon, N. A. Memon, "Flexural stressstrain behavior of rc beams made with partial replacement of coarse aggregates with coarse aggregates from old concrete: Part-1: 1:2:4 ratio", Engineering Technology and Applied Science Research, Vol. 8, No. 3, pp. 3048-3053, 2018

[6] M. Oad, A. H. Buller, B. A. Memon, N. A. Memon, S. Sohu, "Flexural stress-strain behavior of rc beams made with partial replacement of coarse aggregates with recyclable concrete aggregate: Part-2: Rich mix", Engineering Technology and Applied Science Research, Vol. 8, No. 5, pp. $3338-3343,2018$

[7] A. H. Buller, B. A. Memon, "Effect of Fire on Strength of Concrete Cubes with RCA as Coarse Aggregates", 1st National Conference on Civil Engineering-Modern Trends and Advancements, Pakistan, April 28-29, 2014

[8] C. J. Zega, A. A. Di Maio, "Recycled concrete exposed to high temperatures", Magazine of Concrete Research, Vol. 58, No. 10, pp. 675-682, 2006

[9] F. U. A. Shaikh, "Mechanical properties of concrete containing recycled coarse aggregate at and after exposure to elevated temperatures", Structural Concrete, Vol. 19, No. 2, pp. 400-410, 2018

[10] S. R. Sarhat, E. G. Sherwood, "Residual mechanical response of recycled aggregate concrete after exposure to elevated temperatures", Journal of Materials in Civil Engineering, Vol. 25, No. 11, 2013

[11] I. Adebakin, T. Ipaye, "Effect of elevated temperature on the compressive strength of recycled aggregate concrete", Journal of Engineering Sciences, Vol. 5, No. 9, pp. 2278-9472, 2016

[12] G. M. Chen, Y. H. He, H. Yang, J. F. Chen, Y. C. Guo, "Compressive behavior of steel fiber reinforced recycled aggregate concrete after exposure to elevated temperatures", Construction and Building Materials, Vol. 71, pp. 1-15, 2014

[13] A. Gupta, S. Ghosh, S. Mandal, "Coated recycled aggregate concrete exposed to elevated temperature", Global Journal of Researches in Engineering - Civil and Structural Engineering, Vol. 12, No. 3, 2012

[14] G. Etse, S. M. Vresh, M. Ripani, "Constitutive theory for recycled aggregate concretes subjected to high temperature", Construction and Building Materials, Vol. 111,pp. 43-53, 2016
[15] G. Gowda, B. S. Rao, S. M. Naik, "Behavior of recycled aggregate concrete on exposed to elevated temperature", International Journal of Civil Engineering, Vol. 4, No. 6, pp. 5-13, 2017

[16] ASTM, Active Standard ASTM C131/C131M: Standard Test Method for Resistance to Degradation of Small-Size Coarse Aggregate by Abrasion and Impact in the Los Angeles Machine, ASTM, 2008

[17] ASTM, Active Standard ASTM C293/C293M-16: Standard Test Method for Flexural Strength of Concrete (Using Simple Beam with CenterPoint Loading), ASTM, 2008

[18] A. H. Buller, M. Oad, B. A. Memon, "Flexural strength of reinforced concrete rac beams exposed to 6-hour rire: Part 2: Rich mix", Engineering Technology and Applied Science Research, Vol. 9, No. 1, pp. 3813-3816, 2019 